\title{
Effects of Neuroendocrine CB1 Activity on Adult Leydig Cells
}

\author{
Gilda Cobellis', Rosaria Meccariello², Rosanna Chianese', Teresa Chioccarelli', \\ Silvia Fasano ${ }^{1}$ and Riccardo Pierantoni ${ }^{1 *}$
}

'Dipartimento di Medicina Sperimentale, Seconda Università di Napoli, Napoli, Italy, ${ }^{2}$ Dipartimento di Scienze Motorie e del Benessere, Università di Napoli Parthenope, Napoli, Italy

Endocannabinoids control male reproduction acting at central and local level via cannabinoid receptors. The cannabinoid receptor CB1 has been characterized in the testis, in somatic and germ cells of mammalian and non-mammalian animal models, and its activity related to Leydig cell differentiation, steroidogenesis, spermiogenesis, sperm quality, and maturation. In this short review, we provide a summary of the insights concerning neuroendocrine CB1 activity in male reproduction focusing on adult Leydig cell ontogenesis and steroid biosynthesis.

Keywords: CB1, endocannabinoids, Leydig cells, steroidogenesis, spermatogenesis, testis

\section{INTRODUCTION}

OPEN ACCESS

Edited by: Honoo Satake, Suntory Institute for Bioorganic Research, Japan

Reviewed by: Shogo Haraguchi,

Waseda University, Japan Takashi Yazawa,

Asahikawa Medical University, Japan

*Correspondence:

Riccardo Pierantoni riccardo.pierantoni@unina2.it

Specialty section: This article was submitted to Experimental Endocrinology, a section of the journal Frontiers in Endocrinology

Received: 29 February 2016 Accepted: 09 May 2016 Published: 03 June 2016

Citation:

Cobellis $G$, Meccariello $R$, Chianese R, Chioccarelli T, Fasano S and Pierantoni $R$ (2016) Effects of Neuroendocrine CB1 Activity on Adult Leydig Cells.

Front. Endocrinol. 7:47. doi: 10.3389/fendo.2016.00047
Since the identification and the cloning of cannabinoid receptor 1 (CB1) from mammalian brain $(1,2)$, the deep involvement of CB1 signaling in several physiological functions emerged $(3,4)$. Besides central control of processes, such as reproduction, neuroendocrine functions, stress, food intake, neurogenesis, memory, thermogenesis, and pain (3-7), CB1 exerts direct activity in male and female reproductive and non-reproductive cells and tissues (3, 4, 8-11). This membrane G-proteincoupled receptor has the ability to bind endogenous cannabinoids [i.e., anandamide (AEA) and 2-arachidonoylglycerol (2-AG)], phytocannabinoids [i.e., $\Delta^{9}$-tetrahydrocannabinol (THC), the main psychoactive constituent of Cannabis sativa] and synthetic antagonists and agonists [i.e., SR141716 and HU-210, respectively] $(8,12)$. Its activity strongly depends on ligand availability whose tone is endogenously modulated by the fatty acid amide hydrolase (FAAH). Here, we provide a brief summary of the insights concerning direct/indirect effects of CB1 activity on adult Leydig cell (ALC) ontogenesis and steroid biosynthesis.

\section{CB1 ACTIVITY AND ONTOGENESIS OF ALC}

CB1 is expressed and functionally active early during the development, when it regulates embryonic and trophoblast stem cell survival, and the differentiation of several adult specialized tissues (13). CB1 activity has been shown to regulate proliferation and differentiation of mesoderm-derived mesenchymal stem cells, with a key role in cellular differentiation of several peripheral tissues including adipocytes, osteoblasts, skeletal muscle, and epithelial cells (13). A key role for CB1 has further emerged in ALC development, in both rat and mouse (14). Ontogenesis of these cells occurs postnatally from undifferentiated mesenchymal-like stem cells localized in the interstitial compartment of testis. Four distinct stages of the ALC development have been identified and characterized: (i) the stem Leydig cells, i.e., spindle-shaped interstitial mesenchymal cells able of self-renewal, differentiation, and replenishment of the Leydig cell niche; (ii) the progenitor Leydig cells deriving from stem Leydig cells and differentiating into (iii) immature Leydig cells; and (iv) the mature/ALCs originating from the immature ones through a single proliferation cycle (15). During postnatal development of rat testis (14), CB1 is expressed in the interstitial compartment from the early postnatal days. Later, with the 
appearance of round spermatids, CB1 is localized in the tubular compartment. In interstitial cells, CB1 expression is related to stem and/or progenitor cells committed to differentiate into immature Leydig cells. Its expression shuts down in immature Leydig cells when these cells undergo proliferation to produce fully developed ALC (14). Afterward, CB1 results to be stably expressed in these steroid-secreting cells suggesting a direct effect in the modulation of steroidogenesis. In agreement with these observations, CB1 activation inhibits basal testosterone secretion in vivo and in vitro (16), while its inactivation promotes the downregulation of neuroendocrine axis, decrease of testosterone and estradiol levels, and the development of few ALC as well, thus suggesting an involvement of CB1 in steroidogenesis and ALC ontogenesis $(14,16-19)$. Interestingly, as observed in adipocytes during their differentiation (13), CB1 seems to be positively related to differentiation events supervising the ontogenesis of Leydig cells and negatively with respect to their proliferation.

\section{CB1 ACTIVITY AND PRODUCTION OF SEX HORMONES}

Hormonal milieu and a set of local modulators sustain the progression of spermatogenesis and the formation/release of high quality sperm (20). Thus, the testicular biosynthesis of testosterone - the classical male hormone - primarily requires the release of hypothalamic gonadotropin-releasing hormone $(\mathrm{GnRH})$, which in turn induces the release in the bloodstream of pituitary gonadotropins (21).

$\mathrm{CB} 1$ has a leading role in the production of sex hormones; both THC and AEA repress testosterone secretion via inhibition of GnRH and gonadotropins synthesis/release (3, 10, 11, 16, 22-29), whereas sex steroids affect CB1 expression and endocannabinoid levels in the anterior pituitary gland (30). As a consequence, inhibitory effects on neuroendocrine axis $(10,11,18)$, sexual behavior (28), and sperm quality (3, 9, 18, 19, 31-34) have been observed. In testis, besides spermatids and Sertoli cells (14, 34, 35), CB1 is expressed in the steroid-secreting ALC $(14,16,36)$, thus suggesting direct effects on the modulation of ALC activity. Consistently, CB1 and the endovanilloid receptor TRPV1 exert direct, but opposite, effects on testicular $\mathrm{GnRH}$ signaling $(36,37)$, one of the main testicular bioregulators of spermatogenesis and steroidogenesis $(21,38,39)$.

Thus, efforts to define the detailed molecular mechanisms to clarify how endocannabinoids regulate testosterone production in vertebrates have been made. In this respect, data from the anuran amphibian Pelophylax esculentus recently added insights in this intriguing story. In fact, in vitro incubations of frog testis and in vivo treatment with AEA have been carried out to analyze the expression of cytochrome P450 17 $\alpha$-hydroxylase/17,20 lyase (cyp17) and 3 $\beta$-hydroxysteroid dehydrogenase/D-5-4 isomerase $(3 \beta-H S D)$, key enzymes in sex steroid biosynthesis. Interestingly, the in vivo treatment only had an effect on steroidogenesis, thus suggesting that the functionality of the hypothalamus-pituitary axis is essential to support the role of endocannabinoids in the regulation of steroidogenesis in amphibians (40). However, the decrease of cyp 17 may involve receptors other than CB1 since SR141716 administration does not restore its expression to control level.

Since CB1 has the ability to regulate, directly or indirectly, the activity of hypothalamic GnRH [see review in Ref. (29, $11)$ ] in different cell lines (41), as well as in mammalian (24, 42) and non-mammalian vertebrate species $(25,26,43)$, and endocannabinoids are in sharp contrast with kisspeptins, the emerging positive regulators of $\mathrm{GnRH}$ system at both central and testicular level $(44,45)$. Their involvement in the control of ALC activity (45-47), in the regulation of estrogen-dependent reproductive functions (47), and spermatogenesis progression (47) has recently been suggested. Hence, the last insight in CB1 activity and testosterone production is considering kisspeptin system as new cannabinoid target in the hypothalamus. In fact, CB1 activation induces the downregulation of kiss1, the gene encoding kisspeptin, in male rats under stress condition (48) but also in frog testis, under physiological conditions (49). In particular, in frog, the molecular mechanism has recently been elucidated. In fact, in vivo administration of AEA, via $\mathrm{CB} 1$, decreases the transcription level of $\mathrm{GnRH}$, ligands and receptors, in the diencephalon, but also negatively affects Kiss1 and kisspeptin receptor GPR54 in both diencephalon and testis. As a consequence, intratesticular testosterone level decreases and estradiol production increases due to the parallel increase of the P450 aromatase (cyp19) mRNA/protein (49). Therefore, the endocrine route well integrates with the local circuitry that modulates AEA tone by FAAH, the major checkpoint of endocannabinoid signaling in vertebrates occurring via estrogen biosynthesis in both mammalian and non-mammalian testis (49-51). In fact, in vitro incubations with AEA or $17 \beta$-estradiol both increase the FAAH levels, and AEA effects are fully counteracted by the anti-estrogen ICI182780 (49). Therefore, high AEA tone, via cyp19, induces estradiol biosynthesis with subsequent FAAH production and AEA hydrolysis. Thus, AEA may control testis physiology - centrally - acting through kisspeptin system and - locally - modulating its tone via the biosynthesis of estradiol, which in turn targets FAAH protein (49). The direct activity of AEA exerted via CB1 on cyp19 is confirmed by the characterization of $\mathrm{CB}^{-/-}$mice, a model that efficiently synthesizes LH but shows low LH, testosterone, and estradiol levels in the bloodstream $(16,18,19)$. Besides the impairment of GnRH signaling $(18,19)$ and the fewer ALC (14) responsible for LH drop and testosterone depletion, respectively, $C B 1^{-/-}$mice express low cyp19, but normal $3 \beta-H S D$ mRNA levels $(18,19)$, suggesting a direct $\mathrm{CB} 1$ activity in the control of estradiol biosynthesis.

\section{CLOSING REMARKS}

The use of mammalian and non-mammalian animal models should be considered useful tool for studying the involvement of endocannabinoids in the regulation of evolutionarily conserved biological processes such as spermatogenesis $(25,39,52)$. Endocannabinoid system has been characterized in Sertoli and germ cells, while very few information about ALC are available. Since the central role played by ALC in the regulation of testicular activity via endocannabinoid system, we argue that studies should be addressed in this direction. 


\section{AUTHOR CONTRIBUTIONS}

GC and RM: conception and design of the work, critical revision, and final version approval; RC and TC: manuscript drafting; and SF and RP: final version approval.

\section{REFERENCES}

1. Devane WA, Dysarz FA, Johnson MR, Melvin LS, Howlett AC. Determination and characterization of a cannabinoid receptor in rat brain. Mol Pharmacol (1988) 34:605-13.

2. Matsuda LA, Lolait SJ, Brownstein MJ, Young AC, Bonner TI. Structure of a cannabinoid receptor and functional expression of the cloned cDNA. Nature (1990) 346:561-4. doi:10.1038/346561a0

3. Wang H, Dey SK, Maccarrone M. Jekyll and Hyde: two faces of Cannabinoid signaling in male and female fertility. Endocr Rev (2006) 27:427-48. doi:10.1210/er.2006-0006

4. Pertwee RP, editor. Endocannabinoids. Handbook of Experimental Pharmacology. (Vol. 231) Germany: Springer International Publisher Science, Technology, Medicine (2015). p. 1-475.

5. Wenger T, Moldrich G. The role of endocannabinoids in the hypothalamic regulation of visceral function. Prostaglandins Leukot Essent Fatty Acids (2002) 66:301-7. doi:10.1054/plef.2001.0353

6. Pagotto U, Marsicano G, Cota D, Lutz B, Pasquali R. The emerging role of the endocannabinoid system in endocrine regulation and energy balance. Endocr Rev (2006) 27:73-100. doi:10.1210/er.2005-0009

7. Fride E. Endocannabinoids in the central nervous system - an overview. Prostaglandins Leukot Essent Fatty Acids (2002) 66:221-33. doi:10.1054/ plef.2001.0360

8. Cacciola G, Chianese R, Chioccarelli T, Ciaramella V, Fasano S, Pierantoni $\mathrm{R}$, et al. Cannabinoids and reproduction: a lasting and intriguing history. Pharmaceuticals (2010) 3:3275-323. doi:10.3390/ph3103275

9. Maccarrone M. Endocannabinoids: friends and foes of reproduction. Prog Lipid Res (2009) 48:344-54. doi:10.1016/j.plipres.2009.07.001

10. Battista N, Meccariello R, Cobellis G, Fasano S, Di Tommaso M, Pirazzi V, et al. The role of endocannabinoids in gonadal function and fertility along the evolutionary axis. Mol Cell Endocrinol (2012) 355:1-14. doi:10.1016/j. mce.2012.01.014

11. Meccariello R, Battista N, Bradshaw HB, Wang H. Updates in reproduction coming from the endocannabinoid system. Int J Endocrinol (2014) 2014:412354. doi:10.1155/2014/412354

12. Litwack G. Anandamide and endogenous cannabinoid. Vitamins \& Hormones. (Vol. 81) Elsevier Science Publishing Co Inc., (2009).

13. Galve-Roperh I, Chiurchiù V, Díaz-Alonso J, Bari $M$, Guzmán $M$, Maccarrone M. Cannabinoid receptor signaling in progenitor/stem cell proliferation and differentiation. Prog Lipid Res (2013) 52:633-50. doi:10.1016/j. plipres.2013.05.004

14. Cacciola G, Chioccarelli T, Mackie K, Meccariello R, Ledent C, Fasano S, et al. Expression of type-1 cannabinoid receptor during rat postnatal testicular development: possible involvement in adult leydig cell differentiation. Biol Reprod (2008) 79:758-65. doi:10.1095/biolreprod.108.070128

15. Chen H, Ge RS, Zirkin BR. ALC: from stem cells to aging. Mol Cell Endocrinol (2009) 306:9-16. doi:10.1016/j.mce.2009.01.023

16. Wenger T, Ledent C, Csernus V, Gerendai I. The central cannabinoid receptor inactivation suppresses endocrine reproductive functions. Biochem Biophys Res Commun (2001) 284:363-8. doi:10.1006/bbrc.2001.4977

17. Fasano S, Meccariello R, Cobellis G, Chianese R, Cacciola G, Chioccarelli $\mathrm{T}$, et al. The endocannabinoid system: an ancient signaling involved in the control of male fertility. Ann N Y Acad Sci (2009) 1163:112-24. doi:10.1111/j.1749-6632.2009.04437.x

18. Cacciola G, Chioccarelli T, Altucci L, Ledent C, Mason JI, Fasano S, et al. Low 17betaestradiol levels in Cnr1 knock-out mice affect spermatid chromatin remodeling by interfering with chromatin reorganization. Biol Reprod (2013) 88:1-12. doi:10.1095/biolreprod.112.105726

\section{FUNDING}

This work was supported by MIUR (PRIN-Cobellis 2010, PRIN-Meccariello 2010) and Regione Campania (Legge-5 Pierantoni 2007).

19. Cacciola G, Chioccarelli T, Fasano S, Pierantoni R, Cobellis G. Estrogens and spermiogenesis: new insights from type 1 cannabinoid receptor knockout mice. Int J Endocrinol (2013) 2013:501350. doi:10.1155/2013/501350

20. Meccariello R, Fasano S, Pirantoni R, Cobellis G. Modulators of hypothalamic-pituitary-gonadal axis for the control of spermatogenesis and sperm quality in vertebrates. Front Endocrinol (2014) 5:135. doi:10.3389/fendo.2014. 00135

21. Pierantoni R, Cobellis G, Meccariello R, Fasano S. Evolutionary aspects of cellular communication in the vertebrate hypothalamo-hypophysio-gonadal axis. Int Rev Cytol (2002) 218:69-141. doi:10.1016/S0074-7696(02)18012-0

22. Murphy LL, Muñoz RM, Adrian BA, Villanúa MA. Function of cannabinoid receptors in the neuroendocrine regulation of hormone secretion. Neurobiol Dis (1998) 5:432-46.

23. Wenger T, Fernández-Ruiz JJ, Ramos JA. Immunocytochemical demonstration of CB1 cannabinoid receptors in the anterior lobe of the pituitary gland. J Neuroendocrinol (1999) 11:873-8. doi:10.1046/j.1365-2826.1999.00402.x

24. Scorticati C, Fernández-Solari J, De Laurentiis A, Mohn C, Prestifilippo JP, Lasaga M, et al. The inhibitory effect of anandamide on luteinizing hormone-releasing hormone secretion is reversed by estrogen. Proc Natl Acad Sci U S A (2004) 101:11891-6. doi:10.1073/pnas.0404366101

25. Chianese R, Cobellis G, Pierantoni R, Fasano S, Meccariello R. Nonmammalian vertebrate models and the endocannabinoid system: relationship with gonadotropin-releasing hormone. Mol Cell Endocrinol (2008) 286:S4651. doi:10.1016/j.mce.2008.01.009

26. Meccariello R, Franzoni MF, Chianese R, Cottone E, Scarpa D, Donna D, et al. Interplay between the endocannabinoid system and GnRH-I in the forebrain of the anuran amphibian Rana esculenta. Endocrinology (2008) 149:2149-58. doi:10.1210/en.2007-1357

27. Pierantoni R, Cobellis G, Meccariello G, Cacciola G, Chianese R, Chioccarelli $\mathrm{T}$, et al. CB1 activity in male reproduction: mammalian and nonmammalian animal models. Vitam Horm (2009) 81:367-87. doi:10.1016/ S0083-6729(09)81014-5

28. Gorzalka BB, Hill MN, Chang SC. Male-female differences in the effects of cannabinoids on sexual behaviour and gonadal hormone function. Horm Behav (2010) 58:91-9. doi:10.1016/j.yhbeh.2009.08.009

29. Bovolin P, Cottone E, Pomatto V, Fasano S, Pierantoni R, Cobellis G, et al. Endocannabinoids are involved in male vertebrate reproduction: regulatory mechanism at central and gonadal level. Front Endocrinol (2014) 5:54. doi:10.3389/fendo.2014.00054

30. González S, Bisogno T, Wenger T, Manzanares J, Milone A, Berrendero F, et al. Sex steroid influence on cannabinoid $\mathrm{CB}(1)$ receptor mRNA and endocannabinoid levels in the anterior pituitary gland. Biochem Biophys Res Commun (2000) 270:260-6. doi:10.1006/bbrc.2000.2406

31. Cacciola G, Chioccarelli T, Altucci L, Viggiano A, Fasano S, Pierantoni R, et al. Nuclear size as estrogen-responsive chromatin quality parameter of mouse spermatozoa. Gen Comp Endocrinol (2013) 193:201-9. doi:10.1016/j. ygcen.2013.07.018

32. Ricci G, Cacciola G, Altucci L, Meccariello R, Pierantoni R, Fasano S, et al. Endocannabinoid control of sperm motility: the role of epididymus. Gen Comp Endocrinol (2007) 153:320-2. doi:10.1016/j.ygcen.2007.02.003

33. Cobellis G, Ricci G, Cacciola G, Orlando P, Petrosino S, Cascio MG, et al. A gradient of 2-arachidonoylglycerol regulates mouse epididymal sperm cell start-up. Biol Reprod (2010) 82:451-8. doi:10.1095/biolreprod.109.079210

34. Chioccarelli T, Cacciola G, Altucci L, Lewis SE, Simon L, Ricci G, et al Cannabinoid receptor 1 influences chromatin remodeling in mouse spermatids by affecting content of transition protein 2 mRNA and histone displacement. Endocrinology (2010) 151:5017-29. doi:10.1210/en. 2010-0133 
35. Cobellis G, Cacciola G, Scarpa D, Meccariello R, Chianese R, Franzoni MF, et al. Endocannabinoid system in frog and rodent testis: type-1 cannabinoid receptor and fatty acid amide hydrolase activity in male germ cells. Biol Reprod (2006) 75:82-9. doi:10.1095/biolreprod.106.051730

36. Chianese R, Ciaramella V, Scarpa D, Fasano S, Pierantoni R, Meccariello R. Anandamide regulates the expression of GnRH1, GnRH2, and GnRH-Rs in frog testis. Am J Physiol Endocrinol Metab (2012) 303:E475-87. doi:10.1152/ ajpendo.00086.2012

37. Chianese R, Ciaramella V, Scarpa D, Fasano S, Pierantoni R, Meccariello R. Endocannabinoids and endovanilloids: a possible balance in the regulation of the testicular GnRH signaling. Int J Endocrinol (2013) 2013:904748. doi:10.1155/2013/904748

38. Chianese R, Chioccarelli T, Cacciola G, Ciaramella V, Fasano S, Meccariello R, et al. The contribution of lower vertebrate animal models in human reproduction research. Gen Comp Endocrinol (2011) 171:17-27. doi:10.1016/j. ygcen.2010.12.011

39. Pierantoni R, Cobellis G, Meccariello R, Cacciola G, Chianese R, Chioccarelli $\mathrm{T}$, et al. Testicular gonadotropin-releasing hormone activity, progression of spermatogenesis, and spermtransport in vertebrates. Ann N Y Acad Sci (2009) 1163:279-91. doi:10.1111/j.1749-6632.2008.03617.x

40. Chianese R, Ciaramella V, Fasano S, Pierantoni R, Meccariello R. Hypothalamus-pituitary axis: an obligatory target for endocannabinoids to inhibit steroidogenesis in frog testis. Gen Comp Endocrinol (2014) 205:88-93. doi:10.1016/j.ygcen.2014.02.010

41. Gammon CM, Freeman GM Jr, Xie W, Peterson SL, Wetsel WC. Regulation of gonadotropin-releasing hormone secretion by cannabinoids. Endocrinology (2005) 146:4491-9. doi:10.1210/en.2004-1672

42. Farkas I, Kallò I, Deli L, Vida B, Hrabovszky E, Fekete C, et al. Retrograde endocannabinoid signaling reduces GABA-ergic synaptic transmission to gonadotropin-releasing hormone neurons. Endocrinology (2010) 151:581829. doi:10.1210/en.2010-0638

43. Chianese R, Ciaramella V, Fasano S, Pierantoni R, Meccariello R. Anandamide modulates the expression of GnRH-II and GnRH-Rs in frog, Rana esculenta, diecephalon. Gen Comp Endocrinol (2011) 173:389-95. doi:10.1016/j. ygcen.2011.07.001

44. Chianese R, Ciaramella V, Fasano S, Pierantoni R, Meccariello R. Kisspeptin drives germ cell progression in the anuran amphibian Pelophylaxesculentus: a study carried out in ex vivo testes. Gen Comp Endocrinol (2015) 211:81-91. doi:10.1016/j.ygcen.2014.11.008

45. Meccariello R, Chianese R, Chioccarelli T, Ciaramella V, Fasano S, Pierantoni $\mathrm{R}$, et al. Intra-testicular signals regulate germ cell progression and production of qualitatively mature spermatozoa in vertebrates. Front Endocrinol (2014) 5:69. doi:10.3389/fendo.2014.00069

46. Salehi S, Adeshina I, Chen H, Zirkin BR, Hussain MA, Wondisford F, et al. Developmental and endocrine regulation of kisspeptin expression in mouse ALC. Endocrinology (2015) 156:1514-22. doi:10.1210/en.2014-1606

47. Chianese R, Ciaramella V, Fasano S, Pierantoni R, Meccariello R. Kisspeptin receptor, GPR54, as a candidate for the regulation of testicular activity in the frog Rana esculenta. Biol Reprod (2013) 88:73. doi:10.1095/biolreprod.112. 103515

48. Karamikheirabad M, Behzadi G, Faghihi M, Raoofian R, EjtemaeiMehr S, Zuure WA, et al. A role for endocannabinoids in acute stress-induced suppression of the hypothalamic-pituitary-gonadal axis in male rats. Clin Exp Reprod Med (2013) 40:155-62. doi:10.5653/cerm.2013.40.4.155

49. Ciaramella V, Meccariello R, Chioccarelli T, Sirleto M, Fasano S, Pierantoni $\mathrm{R}$, et al. Anandamide acts via kisspeptin in the regulation of testicular activity of the frog, Pelophylaxesculentus. Mol Cell Endocrinol (2016) 420:75-84. doi:10.1016/j.mce.2015.11.011

50. Rossi G, Gasperi V, Paro R, Barsacchi D, Cecconi S, Maccarrone M. Folliclestimulating hormone activates fatty acid amide hydrolase by protein kinase $\mathrm{A}$ and aromatase-dependent pathways in mouse primary Sertoli cells. Endocrinology (2007) 148:431-9. doi:10.1210/en.2006-0969

51. Grimaldi P, Pucci M, Di Siena S, Di Giacomo D, Pirazzi V, Geremia R, et al. The faah gene is the first direct target of estrogen in the testis: role of histone demethylase LSD1. Cell Mol Life Sci (2012) 69:4177-90. doi:10.1007/ s00018-012-1074-6

52. Cacciola G, Chioccarelli T, Ricci G, Meccariello R, Fasano S, Pierantoni R, et al. The endocannabinoid system in vertebrate male reproduction: a comparative overview. Mol Cell Endocrinol (2008) 286:S24-30. doi:10.1016/j. mce.2008.01.004

Conflict of Interest Statement: The authors declare that the research was conducted in the absence of any commercial or financial relationships that could be construed as a potential conflict of interest.

Copyright (C) 2016 Cobellis, Meccariello, Chianese, Chioccarelli, Fasano and Pierantoni. This is an open-access article distributed under the terms of the Creative Commons Attribution License (CC BY). The use, distribution or reproduction in other forums is permitted, provided the original author(s) or licensor are credited and that the original publication in this journal is cited, in accordance with accepted academic practice. No use, distribution or reproduction is permitted which does not comply with these terms. 